\title{
The Role of Akan Values on Moral Upbringing of Children in Contemporary Society
}

\author{
Peter Addai-Mensah' (iD) \\ ${ }^{1}$ Department of Religious Studies, Kwame Nkrumah University of Science and Technology, Kumasi Ghana.
}

\begin{abstract}
The issue of children losing much of their values has become very common in recent times. Most African societies are embedded with values and it is very sad to see that children these days are losing their values. Therefore, it is very crucial for Africans to still inculcate good values in their children. This article assesses the role and importance of Akan values in the moral upbringing of children. In writing this article the author uses the literary approach.It is recommended that the rich and time-tested Akan values like honesty, integrity, sincerity, hospitality, responsibility and respect must be retrieved and never be looked down upon. Parents must inculcate these values in the upbringing of children.
\end{abstract}

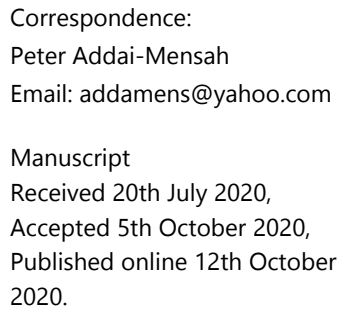

2020.

Keywords: Role, Akan values, Moral, and Child upbringing.

\section{INTRODUCTION}

When the word 'Value', is analyzed, one often looks at some beliefs that are very central to one's life. In many ways, it encourages and underlies one's way of doing things. In a particular culture, values are seen as indispensable elements shared by members of that culture and remain the core principles and collective conceptions of what is considered good in a culture or a society. ${ }^{2}$ Since an individual lives in a community, his/her actions are central to the survival or otherwise of the community or society. Thus, any society that ignores this important issue central to its life will crumble and destroy itself.

Most African traditional societies are embedded in diverse values. These values form the major bulwark that sustains the culture of the people in the society.As opinions differ, in the same way, people see values from a different perspective.However, values can be seen in diverse forms which include; social, moral, religious, political, economic and aesthetic. They all remain essential elements in the lives of an individual as they shape decisions and the way life is led generally. ${ }^{3}$

This article analyzes critically the importance of Akan values. The purpose is to assist parents to inculcate the rich and time-tested Akan values in their children in contemporary Ghanaian society. This will make children in Ghana today not look down on their culture. This will go a long in making them have a cultural identity and a strong personality.

\section{Definition of Concepts}

Values: Values are acquired. They are a cherished way of human existence. They are acquired because one is born into a family and families have norms and rules. Since a person is born and incorporated into the family, the person is supposed to inculcate the family or the community values. Values are attitudes that are dear to the heart of families and communities.

Role: Role deals with the way a person does something. It conforms to what pertains to human development and progress. The role indicates the path or a part one plays.

Morals: Morals are concerned with the principles of right and wrong behavior. They are norms that a family of community sets forth to guide individuals so that the right thing is always done to promote peace and tranquility.

\footnotetext{
Kwame Gyekye, African Cultural Values: An Introduction. (Accra: Sankofa Publishing Company, 1996), 23.

Gabriel E. Idang, "African Culture and Values." Phronimon 16, no. 2(2015):97-111.
} 
Upbringing: Upbringing refers to the treatment and instruction received by a child from its parents throughout its childhood. Upbringing is the way a child is raised or the lessons, instructions and teachings that his or her parents impact. In simple terms, it is the care and training of young ones.

\section{Concept of Values and Moral Upbringing}

According to Idang, values are at the core of human existence. They are highly cherished by individuals and communities. For him, values can be placed on an individual or an object. They denote the price that is put on the person or an object. Since they are highly cherished, values motivate and guide an individual to achieve greater heights. He posits that daily people try to live lives in conformity to what society sees as acceptable. ${ }^{4}$ The author agrees with Idang in saying that in our daily lives people try to live in conformity with societal norms to go against what the society teaches.

Kuada and Chacha are also of the opinion that values and rules of behavior are defined by the members of every society according to their view of life and history. They are therefore not universal. What one may not cherish in his/ her society may be cherished in another society. ${ }^{5}$ Ghanaian values are therefore unique in this respect. A Ghanaian life assumes its proper values only as an integral part of a family and a clan. The author agrees with Kuada and Chacha that values are not universal but rather unique to different societies.

In the opinion of Onwubiko Africans place a high premium on values. One value that is high cherished throughout Africa is the African sense of hospitality. Through this value, Africans readily welcome foreigners and strangers. This is because the social order of the African is not individualistic but rather communalistic. ${ }^{6}$ Among the Africans hospitality is thus an integral part of the African life and which they value very much in their communities. Another important aspect of value that the African cherish is the sense of authority and respect for elders. ${ }^{7}$

The author shares the opinion of John Mbiti, when he says that a person born in Africa cannot grow up and become individualistic. Since a person is always incorporated into a family, the person is supposed to grow up and imbibe the norms and values of the family.For him, it is parents who give birth to a child but it is the whole community that raises him/her.In this way, when a child misbehaves in a community, any adult can call that child to order and even discipline him/her and later on report to the parents of the child. ${ }^{8}$

\section{METHODOLOGY}

The author does not use the qualitative or the quantitative or the mixed-method approaches.In this article the literary approach is used to discuss Akan morality and values helpful for child upbringing.

\section{DISCUSSION}

\section{Akan Morality and Values}

Akans are the largest ethnic group in Ghana.In Akan societies a major concern of its traditional leadership institution is the morality of its leaders. The leadership formation therefore gives much credence to moral education and the black stool among the Akans also contributes to the moral formation of traditional leaders. Nana Addo Dankwa III argues that the belief in ancestors and the symbols such as the black stool (one of the symbols of the Ashanti Kingdom) facilitate moral formation. He states that, many of the rituals performed in the palaces are symbolic gestures. For instance, the cult of ancestors is intended to encourage the living to join the ancestors, their memories also might be preserved for posterity.The practices surrounding the black stool is to challenge the living leadership to pursue values and qualities that will qualify them to become ancestors worth emulating and also to have their stools blackened to preserve their memory. The black stool therefore provides the moral standards and values that leaders are required to pursue. Such values are used for educating in good governance, wholesome relations courage, fairness, chastity, hard work and respect for elders. ${ }^{9}$

Akan formation of values is embedded in traditional symbols, world-views and institutions. Family association facilitates identification and transmission of moral values. The Akan try as much as possible to have symbols which will enforce moral behavior in order not to lead anybody to situations which will bring disgrace to the person and for that matter, the extended family. Any misbehavior by any individu al affects the extended family. Akans fashion out certain things to make it possible for younger generation to learn righteous living from the older generation. Family identities are defined by the values that members exhibit. Through the naming ceremony, marriage rites, puberty rites and funeral rites, families make the effort to distinguish the values that they represent. Analysis of Akan concepts, proverbs and stories

\footnotetext{
Gabriel E .Idang, "Cultural Relativism and the Language of Morals", International Journal of African Cultures and Development 2 (2007).

John Kuada \& Yao Chacha. Ghana, Understanding The People and their Culture. (Accra: Woeli Publishing Services, 1999).

Oliver A. Onuwubiko, “The Christian Mission and Culture in Africa”: International Journal of African Thought, Religion and Culture, 1991: Vol.1 (23).

Onuwubiko, , "The Christian Mission and Culture in Africa"

John Mbiti. African Religion and Philosophy. (London Heinemann Publishers, 1969)

Nana Addo Dankwa III, The Institution of Chieftaincy in Ghana: The Future (Accra: Gold Type Ltd, 2004), 63\&64.
} 
also demonstrate Akan values, which can be considered as the formation values for indigenous formation patterns. The symbols and concepts depict values systems in different areas. The determination of a desirable and acceptable person in Akan society is connected with the exhibition of indigenous knowledge and values. Akan traditional desirable values include hard work, concern for others, fairness, respect for elders, temperance and faithfulness. ${ }^{10}$

\section{Parental Contribution to Moral Upbringing}

Parenting is the process of promoting and supporting a child so that the child can grow up into a mature and a responsible adult. A child is not born with disciplines and values. In the course of their upbringing they inculcate these values from the home and the environment they grow in. It is the duty of the parents to shape the personality of their children through proper guidance and nurturing. A child is born unknown to the moral norms of his society. In the process of the child's growth he/she inculcates these moralities through social interactions and under the guidance of his/her parents. Parenting practices and parenting strategies shape the personality of the child to a greater extent. Parents should exchange thoughts and ideas with their children, grants them freedom and also make sure they are strict when required. They should guide their children in a manner that justifies why they should adopt the taught principle in their life. ${ }^{11}$ This helps children to be well organized and matured thus promoting their moral upbringing. Parents should also set clear rules for children as regards the values they deem important.They should explain the reason behind the rules so the children understand why they are so. Parents should explain the consequences that will occur if any of the rules are broken.They should look for opportunities to teach children lessons about being moral

Furthermore, Darmani argues that, the problems facing young people today have been caused by parents. This is because the Bible clearly admonishes parents that they should teach children the right path so that they will always follow that path and never to abandon that particular path. However, most parents seem not to have taken time to teach children the way they should go. Parents are reaping what they sow in the youth. For Darmani, at home children do not receive proper Christian upbringing; how can they be expected to remain in the church or uphold good moral behavior. Some parents dedicate their children to evil spirits in the name of seeking protection for them. Since they now belong to these evil spirits so to speak, how can we expect them to remain in the church? All kinds of crimes such as abortion, sexual abuse among others are committed by the youth. How can we therefore keep them in the church in other to become moral beings? Thus parental contribution to moral upbringing is very crucial. ${ }^{12}$

\section{Disciplining Children Today}

Despite modernization, disciplining children which is currently lost in many cultures is still appreciated by parents of Akan society. Self-discipline is inculcated by making the children follow laid down rules. At the end parents make sure the child understands values like being respectful or for that matter acquiring any other virtue is not just a matter for discussion but a must in which case the parent takes a commanding or authoritarian stand. Some examples of how Akan parents discipline their children is when the child makes a mistake and parents deliberately take an unusually long time to grant the child's subsequent request for something. Then again some parents take the responsibility to reprimand the child for not showing for example respect, basing their reason on Akan custom and teachings thus inspiring the child. Where the parent suspects the child is not telling the truth or has stolen something, appropriate correctional methods are used including spanking, interrogation and dialogue. ${ }^{13}$ Dialogue is employed for the youth and spanking for younger children to accompany errant behavior for as the Bible admonishes if the rod is spared the child is spoilt (Prov. 13:24 NIV). Where dialogue is used the aim is to point out clearly to the child the benefits of being morally right. For this approach compliments any other disciplinary method applied by the parents in inculcating values into children. Hence today any teacher of moral values must trend carefully and show an appreciation of the child's perception of moral values. This should be done with the understanding that the new ways especially the current social media trends cannot be wished away. ${ }^{14}$ The idea is for everyone to move forward, the parents are willing to pay their instructor as well play a vigilant role while the child must be helped to come out of their current worrisome moral situations. Akan values must be inculcated in young people because it is the only way of enhancing character development and moral upbringing. However, on their part, the child should appreciate this truth because moral people earn high social status and prestige in society, make right decisions, promote peaceful harmonious living within communities, help people to become firmly resolve and possess courage to face challenges in their lives and last but not the least it leads to acquiring blessings from God, and among the Akans connects one to the ancestors.

\footnotetext{
10 Kwabena Opuni- Frimpong. Indigenous Knowledge and Christian Missions. (Accra: SonLife Press, 2012$), 106$.

1 Kojo Wireko-Brobby. Sociology and Spirituality of Life. (Ghana: Good Shepherd Publisher, 2010), 196.

2 Lawrence Darmani. Young and Restless: Challenges Facing the Youth of Today. (Accra: Asempa Publishing Company, 1999$)$, 41.

3 Avidan Milevsky, Melissa Schlechter,Sarah Netter \& Danielle Keehn, "Maternal and Paternal Parenting Styles in Adolescents: Associations with Self-esteem,

Depression and Life Satisfaction". Journal of Child and Family Studies, 16, 2007, (317-328). https://doi.org/10.1007/s10826-006-9066-5

14 Eleanor Maccoby. Socialization and Developmental Change. Child Development, 55, (317-328), 1984.
} 


\section{How to Inculcate Moral Values in children}

It is a fact that cannot be gainsaid that raising up children today is challenging and tiresome. In contemporary societies both parents may be working in order to support and take care of the family unlike in the past when most mothers stayed at home to take care of their children. Children are now mostly left in the hands of nannies and house-helps to take care of them. In spite of this development in raising children, mothers should try as much as they can to be around to help their children's upbringing in a responsible manner. Working parents thus need to take special care to balance both their professional and the parental aspect of their lives. ${ }^{15}$ Parents should provide the child with familiarity and allow friendly exchange of thoughts and ideas, by so doing it helps them to inculcate values in the children. Spending adequate and profitable time with children is very important most especially at the weekends. Taking children outside the home on weekends and holidays can be of great help. In addition to that words of encouragement go a long way to build the selfimage and self-esteem of children.

Furthermore, disciplining children when they go wrong must be critically looked at. Words can hurt and damage a child for life. Constructive criticisms must be encouraged out of love for the upbringing of the child. They should be polite and truthful. They should teach the children to be respectful of others and property. This helps the child in his or her moral upbringing. ${ }^{16}$ In Akan societies, parents should inculcate values in children so that they learn to forgive and forget and become better people. Parents should have the right mindset and create a congenial atmosphere in children upbringing. Th ey should also set strong ground rules.As parents, it is important to set down rules for their children. They should try to make a flexible routine, there should be time to play and time to work. These are all ways of inculcating values in children in contemporary society. By teaching them values parents will be handing over to their children important moral lessons and they will go a long way to live mature and responsible lives. ${ }^{17}$ Parenting thus helps in the inculcation of values in the moral upbringing of children in the African society in general and among the Akan society of Ghana in particular.

\section{The Importance of Moral Values}

Moral values are a set of principles guiding the individual to evaluate what is right or wrong. They are the worthy principles that one follows to distinguish the right from the wrong. Moral values refer to good virtues such as honesty, truthfulness, hard work, respectfulness and many others. Today there is moral decadence in our societies; there are several crime cases, violence, drug abuse and others that are committed by children. There are also several cases of pregnancy, abortions, and sex traders, robbery including others done by children or teenagers in the society. All these are as a result of the moral decadence in our societies. ${ }^{18}$ Morals have social connotations and implications. They are generally accepted by the whole community. Values are priceless in the life of people. They go a long way to assist people to discern what is right or wrong. Moral values are important to teach children because they help in building their character. It shapes individuals' character development and ethical behavior. Parents and teachers must therefore impart values to children in the society. They should encourage children to seek to tell the truth, be disciplined, promote hard work and many others. Moral values are important because they help children to have respect for their parents and the elderly. They also create a caring relationship between one another in society. Moral values also encourage children to be hard-working at home and within their environment.They are important to be taught because moral values have an impact on the child's behavior.Thus, by teaching children moral values they can differentiate what is good from what is bad. ${ }^{19}$

Furthermore, it is important to teach moral values to children.This enables them to inculcate the norms of the family and community.Values help them to identify themselves with their culture which goes a long way to affirm their personality. The result is that they are able to build their confidence and acquire a good self-image. Once children are taught moral values they come to know what is good and wrong. This helps them to stand for what is right and condemn the wrong when they are confronted with issues. In addition to that when children are taught moral values, they are equipped to cope and deal with difficult situations.They will see challenges and difficulties as opportunities to scale over.When children are taught moral values they help them to shun selfish tendencies and become more altruistic.They acquire a sense of belongingness and are able to reach out and assist people in need. They will be more sympathetic and empathetic towards others.

Lastly, morality among the Akans is not founded on religion but on rational reflection regarding what is good for the human welfare. If an Akan is asked the reason for doing good he/she would not say because God wants it or God

\footnotetext{
15 Diana Baumrid. Current Patterns of Parenting Authority. Developmental Psychology Monograph, 4(1. Pt. 2) ,1971

16 Craig Hart, Lloyd Newell, \& Susanne Olsen. Parenting skills and social-communicative competence in childhood. In J. O. Greene, \& B. R. Burleson (Eds.), Handbook of communication and social interaction skills (2003): 753-797.

17 Laurence Steinberg, Nancy E. Darling, and Anne C. Fletcher, Authoritative parenting and adolescent adjustment: An ecological journey. In P. Moen, G. H. Elder, Jr., \& K. Lüscher (Eds.), Examining lives in context: Perspectives on the ecology of human development American Psychological Association. (1995):423-466. https://doi.org/10.1037/10176-012

18 Jujuy Gabarino, Raising Children in a Socially Toxic Environment. (San Francisco: Jossey-Bass), 2004.

19 Anthony S. Bryk, "Musing on the moral life of school", American Journal of Education, 96(2) 1998, 256-290.
} 
says it but he/she would rather say" I would not like it if it is done to me". In other words for Akans the source of moral values are readily attributed to the wellbeing and welfare of the individual. This does not in any way deny God as the source of moral values. This means that when an Akan does something good he/she does it because of the wellbeing and welfare of fellow human being.

\section{RECOMMENDATIONS}

The author will like to make the following recommendations:

1. The rich and time-tested Akan values like honesty, integrity, sincerity, hospitality, responsibility and respect must be retrieved and never be looked down upon by parents.

2. Parents must inculcate these values in the upbringing of children today.

3. Children must not look down on their culture.

4. Children must know that cultural values make them have an identity and make them who they are.

\section{CONCLUSION}

Values are indispensable elements shared by members of a culture and remain the core principle and collective conceptions of what is considered good in a culture or a society.Among the Akan traditional society moral values are highly cherished.They are embedded in diverse values. These values form the major bulwark that sustains the culture of the people in the society. Akan traditional values continue to hold varying degrees of importance in Ghana despite the influence of modernization, globalization or education. In the lives of the Akan, values are one of the basic elements in their daily lives and the Akan are particularly interested in the good moral conduct of their members because it is important to the survival and progress of their society. In African traditional society, moral values are part and parcel of the society. They are seen as coming from God with the ancestors making sure that they are enforced and instilled in people, for them family association facilitates identification and transmission of moral values. Akans fashion out certain things to make it possible for younger generations to learn righteous living from the older generation. In the analysis of Akan concepts, proverbs and stories also demonstrate Akan values, which can be considered as the formation values for indigenous formation patterns. Akan moral values are traditionally not written down. They are orally bequeathed to later generations. Values guide and shape the moral upbringing of the child or an individual by building them up. When values like kindness, generosity, humility, respect for the elderly and compassion are inculcated in children, they enable them to reach out to others and acquire good human relations.Children are not born with values, but in the course of their upbringing they inculcate these values. Parents or elders play a role in inculcating values in children. Hence values are essential part of human life. They form an integral part of their lives and serve as springs of water in their upbringing. Values that children are taught serve as a moral compass that guides and guard them in their adult lives.

\section{ABOUT AUTHOR}

Peter Addai-Mensah is a Catholic priest and a Senior Lecturer at the Department of Religious Studies, Kwame Nkrumah University of Science and Technology, (KNUST) Ghana. His research interests are in Theology and Spirituality.

\section{BIBLIOGRAPHY}

Baumrid, Diana. Current Patterns of Parenting Authority. Developmental Psychology Monograph. 1971.

Bryk, Anthony. S. "Musing on the Moral Life of School", American Journal of Education. 96(2), 1998, 256-290.

Darmani, Lawrence. Young and Restless: Challenges Facing the Youth of Today. Accra: Asempa Publishing Company, 1999.

Gabarino, Jujuy. Raising Children in a Socially Toxic Environment. San Francisco: Jossey-Bass 2004.

Gyekye, Kwame. African Cultural Values: An Introduction. Accra: Sankofa Publishing Company.1996.

Hart, Craig, Newell Lloyd \& Olsen Susanne. Parenting skills and social-communicative competence in childhood. In J.

O. Greene, \& B. R. Burleson (Eds.), Handbook of communication and social interaction skills (2003): 753-797.

Idang, Gabriel. "African Culture and Values.” Phronimon 16, no.2 (2015).

. "Cultural Relativism and the Language of Morals", International Journal of African Cultures and Development 2 (2007).

Kuada, John and Yao Chacha. Ghana, Understanding the People and their Culture. Accra: Woeli Publishing Services, 1999.

Maccoby, Eleanor. Socialization and Developmental Change. Child Development, 1984.

Magesa, Laurenti. African Religion, The Moral Traditions of Abundant Life. New York: Orbis Books Publishing, 1946. 
Mbiti, John. African Religion and Philosophy. London: Heinemann Publishers, 1969.

Milevsky Avidan, Schlechter Melissa, Netter Sarah \& Keehn Danielle, "Maternal and Paternal Parenting Styles in Adolescents: Associations with Self-esteem, Depression and Life Satisfaction". Journal of Child and Family Studies, 16, 2007, (317-328). https://doi.org/10.1007/s10826-006-9066-5

Nana Addo Dankwa III, The Institution of Chieftaincy in Ghana: The Future (Accra: Gold Type Ltd, 2004), 63\&64.

Onuwubiko, Oliver. "The Christina Mission and Culture in Africa": International Journal of African Thought, Religion and Culture, 1 (1991). African Thought, Religion and Culture. Enugu: Bigard Memorial Seminary, 1991.

Opuni-Frimpong, Kwabena. Indigenous Knowledge and Christian Missions. Accra: SonLife Press, 2012.

Rokeach, Milton, The Nature of Human Values. New York: The Free Press, 1973.

Steinberg, L. N. E. Darling and A. C. Fletcher., Authoritative parenting and adolescent adjustment: An ecological journey. In P. Moen, G. H. Elder, Jr., \& K. Lüscher (Eds.), Examining lives in context: Perspectives on the ecology of human development American Psychological Association. (1995):423-466. https://doi.org/10.1037/10176-012

Wireko-Brobby. Kojo. Sociology and Spirituality of Life. Ghana: Good Shepherd Publisher, 2010. 